\title{
Measure of Carbon and Nitrogen Stable Isotope Ratios in Cultured Cells
}

\author{
R. Peteranderl and C. Lechene \\ Department of Medicine, Brigham and Women's Hospital and Harvard Medical School, Boston, Massachusetts, \\ USA
}

\begin{abstract}
We report the measurement of the natural isotope ratios of nitrogen and carbon in subcellular volumes of individual cells among a population of cultured cells using a multi-isotope imaging mass spectrometer (MIMS), [MIMS is the prototype of the NanoSIMS 50, Cameca, France.] We also measured the nitrogen and carbon isotope ratio in cells after they had been cultured in media enriched with the amino acid glycine labeled with either ${ }^{13} \mathrm{C}$ or ${ }^{15} \mathrm{~N}$. The results demonstrate that ${ }^{13} \mathrm{C} /{ }^{12} \mathrm{C}$ and ${ }^{15} \mathrm{~N} /{ }^{14} \mathrm{~N}$ isotope ratios can be measured directly on a subcellular scale. This opens the way for the use of stable isotopes, in particular ${ }^{15} \mathrm{~N}$, as labels to measure the intracellular turnover of biomolecules. Such a capability should help resolve a wide range of biomedical problems. (J Am Soc Mass Spectrom 2004, 15, 478-485) (C) 2004 American Society for Mass Spectrometry
\end{abstract}

$\mathrm{T}$ The fundamental discovery that proteins in biological tissues are turning over was made using a custom-built mass spectrometer to measure the incorporation of ${ }^{15} \mathrm{~N}$-labeled amino acids in proteins of mouse organs [1,2]. Despite the importance of the balance of protein synthesis and degradation for life, these seminal studies could not be extended to the cellular or subcellular scale due to the lack of suitable methodology. Autoradiography of radioactive labels cannot provide quantitative information on protein turnover in cellular organelles. The protein turnover of cellular organelles could be studied if it were possible to measure the enrichment of isotope labels, particularly the stable isotope ${ }^{15} \mathrm{~N}$, in subcellular volumes.

Images of the distribution of ${ }^{15} \mathrm{~N}$ and other isotopes have been provided by secondary ion mass spectrometry [3-14]. Although nitrogen alone does not produce a secondary ion, the secondary cyanide ion, $\mathrm{CN}^{-}$, primarily released from protein-rich regions of biological tissue, provides anatomically recognizable images.

Quantitation of isotope ratios in secondary ion mass spectrometry of biological tissue, however, has been problematic. The evaluation of enrichment in ${ }^{15} \mathrm{~N}$ is based upon the measure of its increase above its natural, terrestrial abundance, calculated from the ${ }^{15} \mathrm{~N} /{ }^{14} \mathrm{~N}$ isotope ratios. Because it is necessary to measure nitrogen from the secondary ion $\mathrm{CN}^{-}$, the mass resolution must be sufficient to allow the separation of the mass 27 isobars, ${ }^{12} \mathrm{C}^{15} \mathrm{~N}$ and ${ }^{13} \mathrm{C}^{14} \mathrm{~N}$. Hindie et al. [15] have reported in elegant experiments the measure of ${ }^{12} \mathrm{C}^{15} \mathrm{~N} /$

Published online February 1, 2004

Address reprint requests to Dr. C. Lechene, National Resource for Imaging Mass Spectrometry, Harvard Medical School/Brigham and Women's Hospital, 65 Landsdowne Street, Rm 535, Cambridge, MA 02139, USA. E-mail: cpl@harvard.edu
${ }^{12} \mathrm{C}^{14} \mathrm{~N},{ }^{13} \mathrm{C}^{14} \mathrm{~N} /{ }^{12} \mathrm{C}^{14} \mathrm{~N}$, and ${ }^{13} \mathrm{C}^{15} \mathrm{~N} /{ }^{12} \mathrm{C}^{14} \mathrm{~N}$ isotope ratios in cultured cells using a CAMECA IMS 3F. The ${ }^{12} \mathrm{C}^{15} \mathrm{~N} /{ }^{12} \mathrm{C}^{14} \mathrm{~N}$ isotope ratio has also been measured in pollen grains [16]. In both cases, however, the data had to be acquired one mass at a time.

Using time-of-flight secondary ion mass spectrometry (TOF-SIMS) in a study of $\mathrm{N}$ assimilation by soil microbes, the value of the ${ }^{12} \mathrm{C}^{15} \mathrm{~N}^{-}$ion current was calculated indirectly from the ${ }^{12} \mathrm{C}^{14} \mathrm{~N}^{-}$ion current, the whole mass 27 ion current (composed of the ${ }^{12} \mathrm{C}^{15} \mathrm{~N}^{-}$, ${ }^{13} \mathrm{C}^{14} \mathrm{~N}^{-}$, and ${ }^{12} \mathrm{C}^{14} \mathrm{~N}^{1} \mathrm{H}^{-}$ions), and the terrestrial (natural) value of the ${ }^{13} \mathrm{C} /{ }^{12} \mathrm{C}$ isotope ratio [17].

A new type of secondary ion mass spectrometer, equipped with the dual capabilities of simultaneously measuring several ion masses and imaging at high resolution, has recently been developed [18]. With this multi-isotope imaging mass spectrometer (MIMS), [the MIMS instrument used in these studies is the prototype of the NanoSIMS 50, Cameca, France], the intensity currents for several secondary ions can be obtained simultaneously, so that small changes in instrumental or sample conditions do not lead to errors in the isotope ratios. The mass resolution for secondary ions is extremely high, making it easy to distinguish the ion ${ }^{12} \mathrm{C}^{15} \mathrm{~N}^{-}$from its isobars ${ }^{13} \mathrm{C}^{14} \mathrm{~N}^{-}$and ${ }^{12} \mathrm{C}^{14} \mathrm{~N}^{1} \mathrm{H}^{-}$. MIMS therefore makes it feasible to use ${ }^{15} \mathrm{~N}$ as a molecular marker for identifying and measuring the turnover of nitrogen-labeled molecules in subcellular domains.

Here, we report the use of MIMS to measure-in parallel一the ${ }^{12} \mathrm{C}^{-},{ }^{13} \mathrm{C}^{-},{ }^{12} \mathrm{C}^{14} \mathrm{~N}^{-}$, and ${ }^{12} \mathrm{C}^{15} \mathrm{~N}^{-}$ion currents in subcellular volumes of cells that had been cultured in normal medium or in media supplemented with the amino acid glycine labeled with either ${ }^{13} \mathrm{C}$ or ${ }^{15} \mathrm{~N}$. The results demonstrate that, for the first time, 
${ }^{13} \mathrm{C} /{ }^{12} \mathrm{C}$ and ${ }^{15} \mathrm{~N} /{ }^{14} \mathrm{~N}$ isotope ratios can be directly measured at a subcellular scale. The capability of this new generation of instruments to directly measure stable isotope ratios lends itself to a wide range of applications in biomedical research. In addition, since stable isotopes can be used as tracers, there are essentially no side effects on the investigated organism. This opens the door to the application of this technology in clinical studies.

\section{Materials and Methods}

\section{Cell Culture and Labeling}

Overall, the methods for cell preparation followed the procedure described by Lechene et al. for culturing cells on silicon chips and for freeze drying under conditions that avoid the redistribution or loss of diffusible molecules [19-21]. In parallel, batches of cells grown on silicon chips were prepared for MIMS experiments by chemical fixation $[22,23]$

Trypsinized rat embryo fibroblast cells (REF 52) were resuspended in 35-mm Petri dishes with $2 \mathrm{ml} \mathrm{DME/F12}$ $+10 \%$ FBS. Each dish contained a 5-mm $\times 5-\mathrm{mm} \mathrm{Si}$ chip, to which cells readily attached (Montco Silicon Technologies, Inc., Spring City, PA; cut to size at Microsystems Technology Laboratories, MIT, Cambridge, MA). The cells were then grown to $80 \%$ confluence, and the chips with the attached cells were transferred to dishes with fresh, prewarmed media supplemented with $1 \mathrm{mM}$ of either ${ }^{13} \mathrm{C}$ glycine $(99 \%)$ or ${ }^{15} \mathrm{~N}$ glycine $(98 \%)$ (Cambridge Isotope Laboratories Inc., Andover, MA). No glycine was added to the control medium (DME/F12 + 10\% FBS). The growth media were replenished every other day. After six days of labeling, the Si chips with the attached cells were split into two groups and treated according to the two following protocols.

\section{Freeze-Drying}

Silicon chips with attached cells were quickly washed in stirred distilled water $\left(4^{\circ} \mathrm{C}\right)$ and then quenched in liquid nitrogen [24]. The samples were kept in liquid nitrogen at $-196^{\circ} \mathrm{C}$ until they could be transferred to a custom-built freeze dryer pre-cooled to $-80^{\circ} \mathrm{C}$ to prevent remodelling of water crystals in the cells. The cells were freeze-dried over a 10-h cooling cycle in a $4.0 \times$ $10^{-7}$ torr vacuum. The samples were then stored in a standard desiccator cabinet under a vacuum of $10^{-3}$ torr at $50{ }^{\circ} \mathrm{C}$ until they were transferred to the MIMS.

\section{Chemical Fixation of Cells}

Silicon chips with attached cells were transferred to 35-mm Petri dishes with $1 \mathrm{ml}$ of prewarmed growth medium. A volume of $1 \mathrm{ml}$ fixative $(2.5 \%$ formaldehyde, $5 \%$ glutaraldehyde, $0.06 \%$ picric acid, $1 \mathrm{M}$ cacodylate buffer, $\mathrm{pH} 7.4,0.06 \% \mathrm{CaCl}_{2}$ ) was added, and the cells were incubated at room temperature for $30 \mathrm{~min}$ utes. The fixative was then aspirated, and the cells were washed four times in PBS. The fixed cells were dried in a standard desiccator cabinet under a vacuum of $10^{-3}$ torr $\left(50^{\circ} \mathrm{C}\right)$ and kept there until they were transferred to the MIMS.

\section{Mass Spectrometric Determination of Isotope Ratios}

Isotope ratios were determined with a multi-isotope imaging mass spectrometer (MIMS). [MIMS is the prototype of the NanoSims50, Cameca, France.] The main components of the instrument are shown in Figure 1. They include the following: The primary column (PC), with a cesium primary ion source (IS) to enhance the yield of negative secondary ions; the objective column $(\mathrm{OC})$, where the same ion optic is used in a coaxial manner to focus the primary beam on the sample and to collect secondary ions; the secondary column (SC) and hexapole (HX), where the secondary ion beam is shaped to match the acceptance of the spectrometer; and the dual-focusing mass spectrometer, a combination of an electrostatic (EP) and a magnetic (MP) sector, which focuses the secondary ions as narrow lines in the focal plane (FP) of the magnet. The transmission at high mass resolution is improved by correcting the main secondorder aperture aberrations as well as by focusing the secondary ion beam in the vertical dimension. Four detectors (MD) can be moved independently along the focal plane to select four masses for detection. Each detector itself consists of a pair of deflection plates (DP) followed by a selection slit (SS) and a miniature electron multiplier (EM). Tuning of the deflection plates, which permits further scanning of the selected small region of the spectrum, greatly improves the final mass selectivity. This instrument provides both parallel detection and high mass resolution with little sacrifice in secondary ion transmission from sample to detector. For example, for the ${ }^{12} \mathrm{C}^{14} \mathrm{~N}^{-}$secondary ion, transmission is at least $70 \%$, while the mass resolution $(\Delta \mathrm{m} / \mathrm{m})$ is 1 in $10^{4}$.

The primary cesium ion beam current for the different experiments varied from 36-40 nA; the energy of the primary beam was $15 \mathrm{keV}$. Measurements were made using a static beam slightly defocused to a spot of $\approx 2 \mu \mathrm{m}$ at the object plane. For typical experiments, Detector 1 was tuned to $12.000 \mathrm{~m} / z$ for ${ }^{12} \mathrm{C}^{-}$, Detector 2 to $13.0034 \mathrm{~m} / \mathrm{z}$ for ${ }^{13} \mathrm{C}^{-}$, Detector 3 to $26.0031 \mathrm{~m} / \mathrm{z}$ for ${ }^{12} \mathrm{C}^{14} \mathrm{~N}^{-}$, and Detector 4 to $27.000 \mathrm{~m} / \mathrm{z}$ for the isobars ${ }^{12} \mathrm{C}^{15} \mathrm{~N}^{-}$and ${ }^{13} \mathrm{C}^{14} \mathrm{~N}^{-} .{ }^{12} \mathrm{C}^{15} \mathrm{~N}^{-}(27.0001 \mathrm{~m} / \mathrm{z})$ and ${ }^{13} \mathrm{C}^{14} \mathrm{~N}^{-}(27.0064 \mathrm{~m} / \mathrm{z})$ were resolved using the deflection plates of the detector.

The cells were selected in the analysis chamber of MIMS using a photomicroscope with an attached CCD camera. Five to ten cells were measured for each data set.

The secondary ion counts for each cell area were 


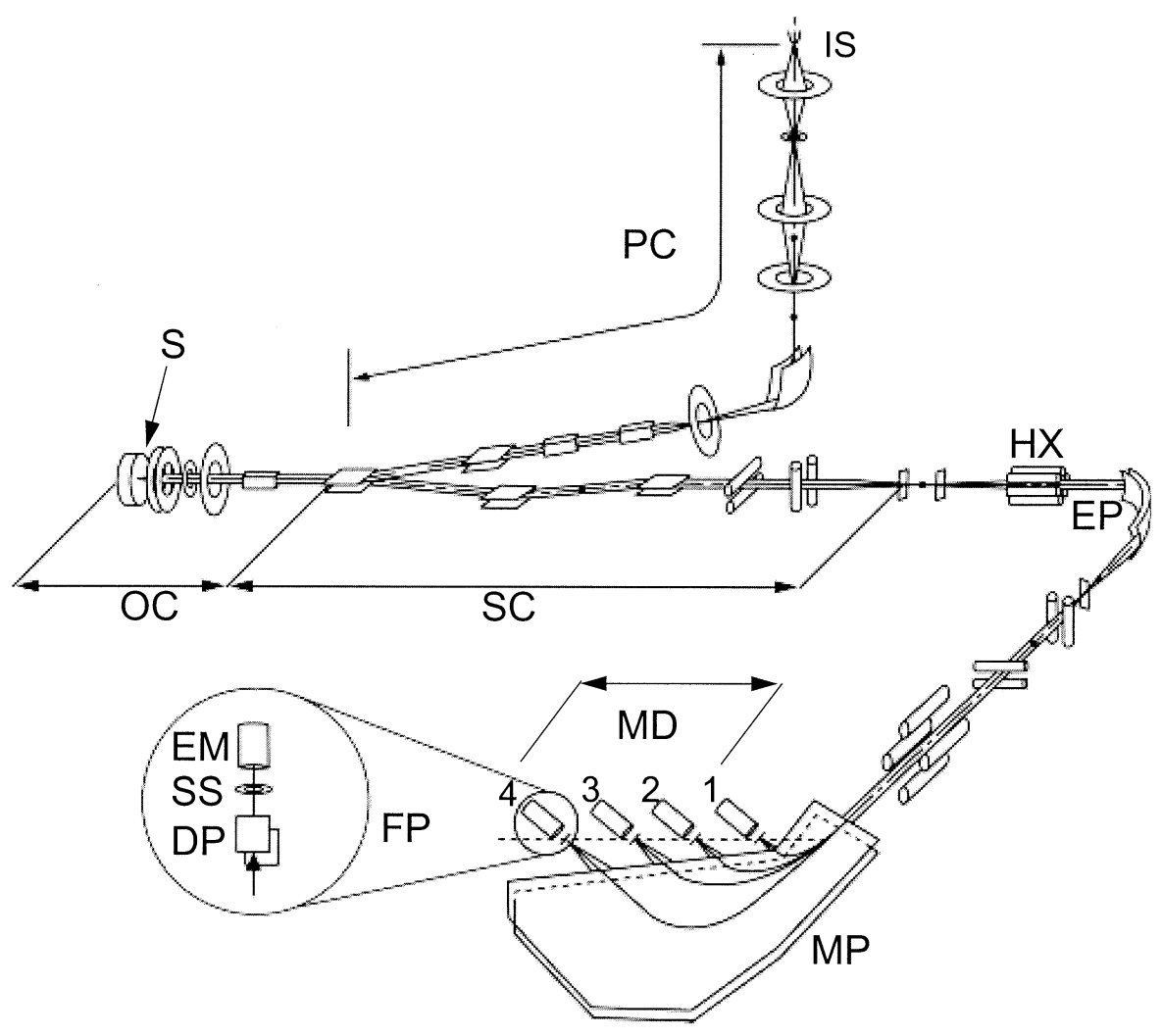

Figure 1. Schematics of the CAMECA NanoSIMS Multi-isotope Imaging Mass Spectrometer (MIMS). IS: Cesium primary ion source. PC: Primary column. OC: Objective column. SC: Secondary column. HX: Hexapole electron lens. EP: Electrostatic sector. MP: Magnetic sector. FP: Focal plane. MD: Multi-detection unit. DP: Deflection plate. SS: Selection slit. EM: Electron multiplier.

averaged from five sets of $6 \times 1$-s measurements, after an initial 6-s equilibration. Isotope ratios were determined directly from the secondary ion current. The ${ }^{15} \mathrm{~N} /{ }^{14} \mathrm{~N}$ isotope ratios were obtained by dividing the counts for ${ }^{12} \mathrm{C}^{15} \mathrm{~N}^{-}$by the simultaneously recorded counts for ${ }^{12} \mathrm{C}^{14} \mathrm{~N}^{-}$. The ${ }^{13} \mathrm{C} /{ }^{12} \mathrm{C}$ isotope ratios were obtained by two methods: By dividing the counts of ${ }^{13} \mathrm{C}^{14} \mathrm{~N}^{-}$by the simultaneously recorded counts of ${ }^{12} \mathrm{C}^{14} \mathrm{~N}^{-}$, and by dividing the counts for ${ }^{13} \mathrm{C}^{-}$by the simultaneously recorded counts for ${ }^{12} \mathrm{C}^{-}$. The precision of these ratios is essentially a function of the secondary ion currents for ${ }^{12} \mathrm{C}^{15} \mathrm{~N}^{-},{ }^{13} \mathrm{C}^{14} \mathrm{~N}^{-}$, or ${ }^{13} \mathrm{C}^{-}$, which were all considerably larger than $1000 \mathrm{~s}^{-1}$ (3\% precision). Data analysis was performed with an SGI O2 workstation using Prophet statistical software (NCRR, NIH).

\section{Results}

\section{High Mass Resolution Scans}

The atomic mass spectra obtained after tuning the instrument on a rat fibroblast cell for the mono-, di- and tri-atomic secondary ions listed in Table 1 are shown in Figure 2. They were acquired by scanning a small region of the mass spectrum across the entrance slit of the detectors, using a potential applied to the deflection plates. The mass lines are sufficiently narrow, with mass resolutions that allow us to discriminate between isobars, such as ${ }^{13} \mathrm{C}^{-}$and ${ }^{12} \mathrm{C}^{1} \mathrm{H}^{-}$(Figure $2 \mathrm{~b}$ ), ${ }^{12} \mathrm{C}^{14} \mathrm{~N}^{-}$ and $\left[{ }^{13} \mathrm{C}\right]_{2}^{-}$(Figure 2c), and ${ }^{12} \mathrm{C}^{15} \mathrm{~N}^{-},{ }^{13} \mathrm{C}^{14} \mathrm{~N}^{-}$, ${ }^{12} \mathrm{C}^{14} \mathrm{~N}^{1} \mathrm{H}^{-}$and $\left[{ }^{13} \mathrm{C}\right]{ }_{2}^{1} \mathrm{H}^{-}$(Figure $2 \mathrm{~d}$ ). It should be noted that the width of the mass selection slit is larger than the mass line being selected. As a consequence, the mass line appears in the recording as a peak with a flat top (Figure 2a). Two adjacent lines may be completely separated and appear in the recording with no valley between their flat peaks (Figure 2a-2c). [Slodzian, G., personal communication.]

For the actual analysis of isotope ratios, the potential of the deflector plates was set at the appropriate values for the desired secondary ions, eliminating any spillover from neighboring mass peaks.

Table 1. Isobars

\begin{tabular}{|c|c|c|}
\hline Ion & a.m.u. & $\mathrm{M} / \Delta \mathrm{M}$ \\
\hline${ }^{13} \mathrm{C}$ & 13.0034 & \multirow{2}{*}{2956} \\
\hline${ }^{12} \mathrm{C}^{1} \mathrm{H}$ & 13.0078 & \\
\hline${ }^{12} \mathrm{C}^{14} \mathrm{~N}$ & 26.0031 & \multirow{2}{*}{7224} \\
\hline$\left[{ }^{13} \mathrm{C}\right]_{2}$ & 26.0067 & \\
\hline${ }^{12} \mathrm{C}^{15} \mathrm{~N}$ & 27.0001 & \multirow{2}{*}{4287} \\
\hline${ }^{13} \mathrm{C}^{14} \mathrm{~N}$ & 27.0064 & \\
\hline${ }^{12} \mathrm{C}^{14} \mathrm{~N}^{1} \mathrm{H}$ & 27.0109 & \multirow[b]{2}{*}{7504} \\
\hline$\left[{ }^{13} \mathrm{C}\right]_{2}{ }^{1} \mathrm{H}$ & 27.0145 & \\
\hline
\end{tabular}



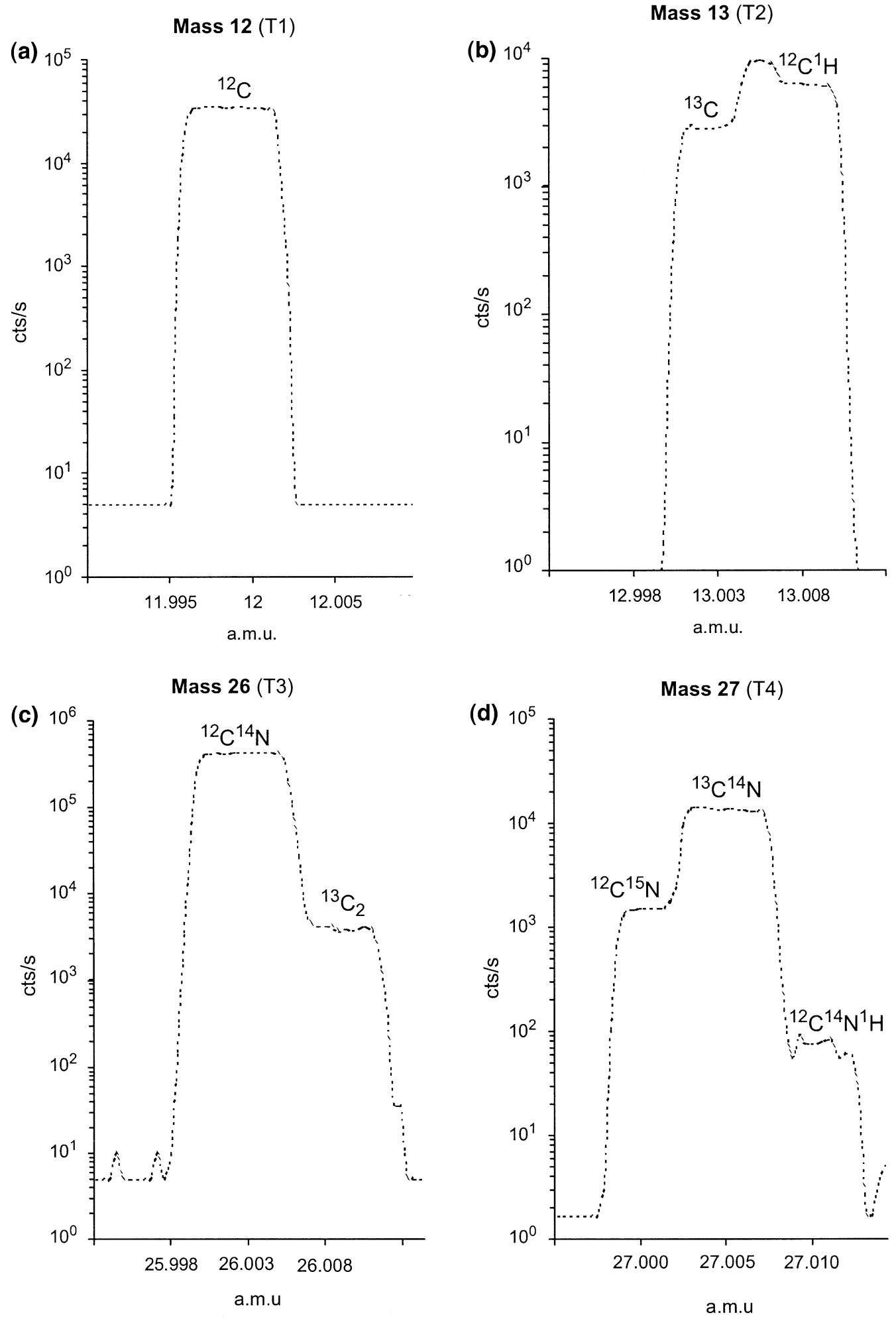

Figure 2. High Resolution Mass Spectra. Resolving power of the NanoSIMS. The detectors T1-T4 are positioned at the focal points for the masses (a) 12 a.m.u., (b) 13 a.m.u., (c) 26 a.m.u., and (d) 27 a.m.u. Varying the potential of the deflector plates selects between different isobaric ions.

\section{Isotope Ratios}

Control isotope ratios (Figure 3). The control ${ }^{15} \mathrm{~N} /{ }^{14} \mathrm{~N}$ isotope ratios were calculated from the secondary ion currents of ${ }^{12} \mathrm{C}^{15} \mathrm{~N}^{-}$and ${ }^{12} \mathrm{C}^{14} \mathrm{~N}^{-}$from cells that had not been supplemented with ${ }^{15} \mathrm{~N}$-glycine. The mean ${ }^{12} \mathrm{C}^{15} \mathrm{~N}^{-} /{ }^{12} \mathrm{C}^{14} \mathrm{~N}^{-}$isotope ratio calculated for freezedried cells is $0.356 \% \pm 0.009 \%$ s.e.m. $(n=16)$. The mean 


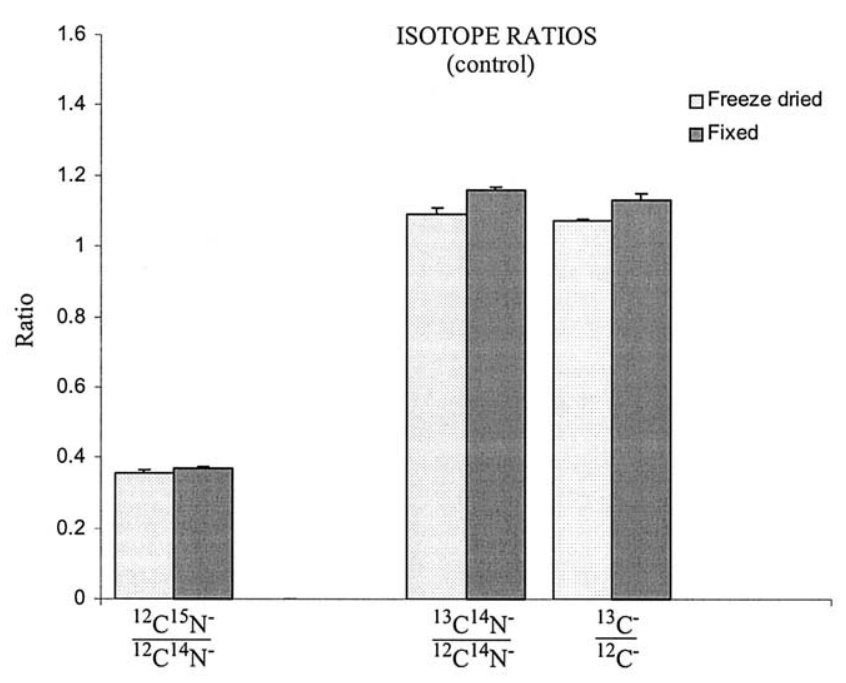

Figure 3. Isotope ratios for control cells. Plotted are the means and the standard errors of the means for the isotope ratios of nitrogen, determined as cyanide ions, and for carbon, determined as cyanide and as carbon ions. The values are given as the ratio of the isotope ion counts $\times 100 \%$.

${ }^{12} \mathrm{C}^{15} \mathrm{~N}^{-} /{ }^{12} \mathrm{C}^{14} \mathrm{~N}^{-}$isotope ratio calculated for chemically fixed cells is $0.372 \% \pm 0.003 \%$ s.e.m. $(n=23)$. These values are not significantly different from the value of the terrestrial ratio of ${ }^{15} \mathrm{~N} /{ }^{14} \mathrm{~N}(0.368 \%)$.

The control ${ }^{13} \mathrm{C} /{ }^{12} \mathrm{C}$ isotope ratios were calculated from the secondary ion currents for ${ }^{12} \mathrm{C}^{-},{ }^{13} \mathrm{C}^{-}$, ${ }^{12} \mathrm{C}^{14} \mathrm{~N}^{-}$, and ${ }^{13} \mathrm{C}^{14} \mathrm{~N}^{-}$from cells that had not received any supplementary ${ }^{13} \mathrm{C}$-glycine. The mean ${ }^{13} \mathrm{C}^{14} \mathrm{~N}^{-} /$ ${ }^{12} \mathrm{C}^{14} \mathrm{~N}^{-}$isotope ratio calculated for freeze-dried cells is $1.092 \% \pm 0.017 \%$ s.e.m. $(n=15)$. This value is not

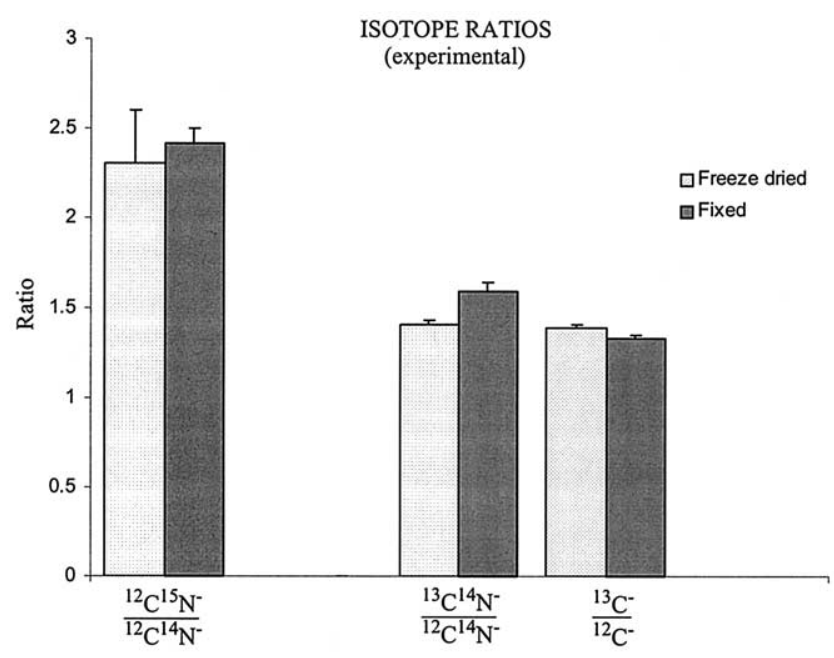

Figure 4. Isotope ratios for cells isotopically labeled with ${ }^{15} \mathrm{~N}$ or ${ }^{13} \mathrm{C}$. Cells were labeled with ${ }^{15} \mathrm{~N}$-glycine (Column Pair 1 ) or ${ }^{13} \mathrm{C}$-glycine (Column Pairs 2 and 3). Plotted are the means and the standard errors of means for the isotope ratios of nitrogen in the case of the ${ }^{15} \mathrm{~N}$-glycine labeled cells, determined as cyanide ions, and for the isotope ratios of carbon in the case of the ${ }^{13} \mathrm{C}$-glycine labeled cells, determined as cyanide ions and as carbon ions. The values are given as the ratio of the isotope ion counts $\times 100 \%$. significantly different from either the value of the natural abundance ratio for ${ }^{13} \mathrm{C} /{ }^{12} \mathrm{C}(1.119 \%)$ or from the ${ }^{13} \mathrm{C} /{ }^{12} \mathrm{C}$ ratio calculated from the ${ }^{13} \mathrm{C}^{-}$and ${ }^{12} \mathrm{C}^{-}$ secondary ion currents, with a mean of $1.071 \% \pm$ $0.007 \%$ s.e.m. $(n=29)$. The mean ${ }^{13} \mathrm{C}^{-} /{ }^{12} \mathrm{C}^{-}$isotope ratio calculated for fixed cells is $1.133 \pm 0.015$ s.e.m. $(n$ $=40$ ). This value is not significantly different from the value of the terrestrial ratio for ${ }^{13} \mathrm{C} /{ }^{12} \mathrm{C}(1.119 \%)$ or from the ${ }^{13} \mathrm{C} /{ }^{12} \mathrm{C}$ ratio calculated from the ${ }^{13} \mathrm{C}^{14} \mathrm{~N}^{-}$and ${ }^{12} \mathrm{C}^{14} \mathrm{~N}^{-}$measurements with a mean $=1.159 \% \pm$ $0.005 \%$ s.e.m. $(n=10)$.

Experimental isotope ratios (Figure 4). The experimental ${ }^{13} \mathrm{C} /{ }^{12} \mathrm{C}$ isotope ratios were calculated from the secondary ion currents for ${ }^{12} \mathrm{C}^{-},{ }^{13} \mathrm{C}^{-},{ }^{12} \mathrm{C}^{14} \mathrm{~N}^{-}$, and ${ }^{13} \mathrm{C}^{14} \mathrm{~N}^{-}$ from cells that had received supplementary ${ }^{13} \mathrm{C}$-glycine. The mean experimental ${ }^{13} \mathrm{C}^{14} \mathrm{~N}^{-} /{ }^{12} \mathrm{C}^{14} \mathrm{~N}^{-}$isotope ratio calculated for freeze-dried cells was $1.399 \% \pm 0.028 \%$ s.e.m. $(n=8)$. This value is equivalent to the value of the ${ }^{13} \mathrm{C} /{ }^{12} \mathrm{C}$ isotope ratio calculated from the ${ }^{13} \mathrm{C}^{-}$and ${ }^{12} \mathrm{C}^{-}$measurements $($mean $=1.385 \% \pm 0.014 \%$ s.e.m. $[n$ $=15]$ ). These values are highly significantly different ( $\mathrm{p}$ $=0.0001$ ) from the value of the natural abundance ratio for ${ }^{13} \mathrm{C} /{ }^{12} \mathrm{C}(1.119 \%)$.

The mean of the experimental ${ }^{13} \mathrm{C}^{14} \mathrm{~N}^{-} /{ }^{12} \mathrm{C}^{14} \mathrm{~N}^{-}$isotope ratio calculated for fixed cells is $1.586 \% \pm 0.054 \%$ s.e.m. $(n=7)$. This value is highly significantly different $(\mathrm{p}<0.0001)$ from the value of the ${ }^{13} \mathrm{C} /{ }^{12} \mathrm{C}$ isotope ratio calculated from the ${ }^{13} \mathrm{C}^{-}$and ${ }^{12} \mathrm{C}^{-}$secondary ion currents, which has a mean $=1.326 \% \pm 0.015 \%$ s.e.m. $(n=$ 11). Both values are highly significantly different from the natural abundance ratio for ${ }^{13} \mathrm{C} /{ }^{12} \mathrm{C}$ of $1.119 \%$ ( $\mathrm{p}=$ 0.0001).

The experimental ${ }^{15} \mathrm{~N} /{ }^{14} \mathrm{~N}$ isotope ratios were calculated from the secondary ion currents of ${ }^{12} \mathrm{C}^{15} \mathrm{~N}^{-}$and ${ }^{12} \mathrm{C}^{14} \mathrm{~N}^{-}$from cells that had been supplemented with ${ }^{15} \mathrm{~N}$-glycine. The mean experimental ${ }^{12} \mathrm{C}^{15} \mathrm{~N}^{-} /{ }^{12} \mathrm{C}^{14} \mathrm{~N}^{-}$ isotope ratio calculated for freeze-dried cells is $2.308 \%$ $\pm 0.297 \%$ s.e.m. $(n=6)$. The mean experimental ${ }^{12} \mathrm{C}^{15} \mathrm{~N}^{-} /{ }^{12} \mathrm{C}^{14} \mathrm{~N}^{-}$isotope ratio calculated for fixed cells is $2.419 \% \pm 0.081 \%$ s.e.m. $(n=10)$. These values are highly significantly different from the terrestrial ${ }^{15} \mathrm{~N} /$ ${ }^{14} \mathrm{~N}$ ratio $(0.368 \%)$.

\section{Secondary Ion Currents}

The secondary ion currents were measured in parallel for the ${ }^{12} \mathrm{C}^{-},{ }^{13} \mathrm{C}^{-},{ }^{12} \mathrm{C}^{14} \mathrm{~N}^{-}$, and ${ }^{12} \mathrm{C}^{15} \mathrm{~N}^{-}$or ${ }^{13} \mathrm{C}^{14} \mathrm{~N}^{-}$ ions from both fixed and freeze-dried cells. The values for secondary ion currents for ${ }^{12} \mathrm{C}^{-}$and ${ }^{12} \mathrm{C}^{14} \mathrm{~N}^{-}$are presented in Figure 5. The values (counts per second) of ${ }^{12} \mathrm{C}^{-}$for fixed cells are: Median $=7807$, mean $=8449 \pm$ 1089 s.e.m. $(n=20)$; for freeze-dried cells, the values are: Median $=21881$, mean $=32819 \pm 7235$ s.e.m. $(n=$ 10). The difference in ${ }^{12} \mathrm{C}^{-}$secondary ion current between fixed cells and freeze-dried cells is highly significant $(\mathrm{p}<0.0001)$. The values (counts per second) of ${ }^{12} \mathrm{C}^{14} \mathrm{~N}^{-}$for fixed cells are: Median $=46037$, mean $=$ $52529 \pm 6125$ s.e.m. $(n=20)$; for freeze-dried cells, the 


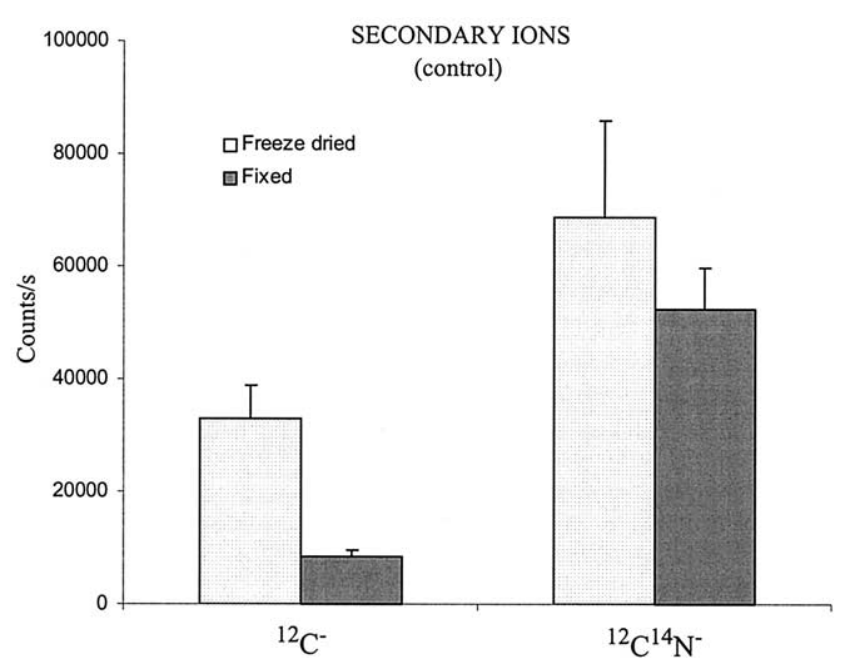

Figure 5. Secondary ion yield. Secondary ion count rates for freeze-dried and fixed cells. Shown are the means and the standard errors of the means for ${ }^{12} \mathrm{C}^{-}$and ${ }^{12} \mathrm{C}^{14} \mathrm{~N}^{-}$secondary ions from control cells.

values are: Median $=55004$, mean $=68779 \pm 17060$ s.e.m. $(n=10)$. Strikingly, there is no statistical difference between ${ }^{12} \mathrm{C}^{14} \mathrm{~N}^{-}$secondary ion currents measured from fixed or freeze-dried cells $(\mathrm{p}=0.75)$.

Similar results were obtained for ${ }^{13} \mathrm{C}^{-}$and ${ }^{12} \mathrm{C}^{15} \mathrm{~N}^{-}$ secondary ion currents. The values (counts per second) of ${ }^{13} \mathrm{C}^{-}$for fixed cells are: Median $=83$, mean $=91 \pm$ 11 s.e.m. $(n=20)$; for freeze-dried cells, the values are: Median $=256$, mean $=357 \pm 77$ s.e.m. $(n=10)$. Again, the difference in ${ }^{13} \mathrm{C}^{-}$secondary ion current between fixed cells and freeze-dried cells is highly significant ( $\mathrm{p}$ $<0.0001$ ). In the case of ${ }^{12} \mathrm{C}^{15} \mathrm{~N}^{-}$the values (counts per second) for fixed cells are: Median $=171$, mean $=193 \pm$ 23 s.e.m. $(n=20)$; for freeze-dried cells, the values are: Median $=212$, mean $=271 \pm 74$ s.e.m. $(n=10)$. In contrast to the results for ${ }^{13} \mathrm{C}^{-}$, there is no statistical difference between ${ }^{12} \mathrm{C}^{15} \mathrm{~N}^{-}$secondary ion currents measured from fixed or freeze-dried cells $(\mathrm{p}=0.78)$.

\section{Discussion}

We simultaneously measured the isotope ratios of ${ }^{13} \mathrm{C} /$ ${ }^{12} \mathrm{C}$ and ${ }^{15} \mathrm{~N} /{ }^{14} \mathrm{~N}$ for subcellular sample volumes of cultured fibroblasts. Overall, the values determined in this study for unlabeled cells are essentially identical to the published natural abundances of these isotope ratios, thus demonstrating the suitability of multi-isotope imaging mass spectrometry for such measurements.

In the second phase of this study, we measured increased isotope ratios after labeling cultured cells with ${ }^{13} \mathrm{C}$ - or ${ }^{15} \mathrm{~N}$-glycine. Incubation of the cells with isotopically labeled glycine for six days was expected to lead to a significant incorporation of the label into newly synthesized protein, together with a high turnover pool of the label in the form of free amino acids, charged aminoacyl tRNAs and other metabolic products. In practice, nitrogen-containing compounds other than protein in whole tissue or cells are quantitatively negligible, since protein is typically about $20 \%$ of tissue wet weight, while nucleic acids (primarily ribosomal RNAs) are less than $2 \%$ of wet weight [25].

Nitrogen does not have a radioactive isotope with a half-life long enough to be used as a tracer in biological experiments. Yet the ability to label bio-organic molecules, particularly proteins or nucleotides, and to follow their intracellular turnover would be of great interest to biological and medical research. MIMS allows us to measure the ratios of stable isotopes of nitrogen, in addition to the determination of non-radioactive carbon isotope ratios. While nitrogen itself is not emitted as an anion due to its low electron affinity, cyanide ions $\left(\mathrm{CN}^{-}\right)$have a high electron affinity $(3.82 \mathrm{eV})$ and are generated with a high yield from biological samples if they are exposed to a bombardment by a cesium ion beam $[15,18]$.

The necessity of detecting nitrogen as the diatomic $\mathrm{CN}^{-}$ion, however, gives rise to additional complications. Since carbon also occurs in the form of two stable isotopes $\left({ }^{12} \mathrm{C}\right.$ and $\left.{ }^{13} \mathrm{C}\right)$, two possible cyanide ions with a nominal mass of $27 \mathrm{~m} / \mathrm{z}$ can be formed: ${ }^{13} \mathrm{C}^{14} \mathrm{~N}^{-}$and ${ }^{12} \mathrm{C}^{15} \mathrm{~N}^{-}$. Since the masses of these two ions differ by only one part in 4272 , very high mass resolution is required to use ${ }^{15} \mathrm{~N}$ as an exogenous label to be detected as ${ }^{12} \mathrm{C}^{15} \mathrm{~N}^{-}$ions. MIMS easily provides such a mass resolution, while maintaining a high transmission coefficient for secondary ions throughout the ion optical system from the sample to the detector $(>70 \%)$.

Determining intracellular isotope ratios of nitrogen requires measuring the count rates of two secondary ions in parallel from the same sample volume under the same conditions. Single channel SIMS has been limited to the evaluation of one secondary ion count rate at a time, thus introducing potential sources of errors in the ratio determination due to the possibility of sample drift, sample degradation under the primary ion beam, or slight changes in instrumental conditions. On the other hand, current TOF-SIMS instruments have neither the necessary mass resolution to discriminate between isobars [8] nor the spatial resolution. These difficulties, however, are resolved by MIMS, which permits the parallel detection of mass 26 simultaneously with mass 27 , providing multiple secondary ion measurements from the same sputtered microscopic volume. In addition, mass 13 and mass 12 counts can be acquired together with mass 26 and mass 27 counts, thus allowing for the simultaneous analysis of the turnover of molecules labeled with ${ }^{13} \mathrm{C}$ and with ${ }^{15} \mathrm{~N}$.

The yields of each ion species vary widely among control cells. Among the parameters that likely will influence the secondary ion yield are: The size of the primary ion beam, the amount and density of the cellular material under the primary ion beam, matrix effect, and the relief of the surface attacked by the primary ion beam. It is reasonable to assume, however, that the pairs of isotopes $\left({ }^{12} \mathrm{C}\right.$ and ${ }^{13} \mathrm{C}$, as well as ${ }^{12} \mathrm{C}^{14} \mathrm{~N}$ and ${ }^{12} \mathrm{C}^{15} \mathrm{~N}$ ) will be influenced by these conditions to 
the same fraction, respectively. Therefore, the variation will "cancel out" in the ratios, which gives the istope ratio method all its value for the measure of turnover. Thus, the value of the nitrogen or carbon isotope ratios will be relatively independent of the parameters influencing the individual ion yields. The variation of the isotope ratios is small compared with the variability of the counts. The coefficients of variation range from 3 to $13 \%$ for the isotope ratio values, compared with a range of values from 52 to $87 \%$ for the secondary ion currents of control cells. This variability most likely reflects local differences at the cellular level and among samples due to growth conditions, the metabolic state of the cells at the time of preparation, and the sample preparation method used.

Two observations underline the precision and accuracy of the instrument used in this study for the determination of isotope ratios of biological samples: First, the fractional increases above the natural abundance values of the ${ }^{15} \mathrm{~N} /{ }^{14} \mathrm{~N}$ and ${ }^{13} \mathrm{C} /{ }^{12} \mathrm{C}$ isotope ratios are equivalent when normalized for the relative difference in natural abundance of the isotopes and for the relative amounts of carbon and nitrogen in biological samples. The natural abundance of ${ }^{13} \mathrm{C}$ is $1.107 \%$ of the total carbon, and the natural abundance of ${ }^{15} \mathrm{~N}$ is $0.3663 \%$ of the total nitrogen. Biological tissues are composed of $61.7 \%$ carbon and $11.0 \%$ nitrogen [26]. Thus, in biological tissues, the ${ }^{13} \mathrm{C}$ background is 16.9fold larger than the ${ }^{15} \mathrm{~N}$ background. If one considers the freeze-dried cells, the increase in ${ }^{15} \mathrm{~N}$ isotope ratio above the natural occurrence is $(2.308 \%-0.3676 \%) /$ $0.3676 \%=5.28$. All conditions being the same, the equivalent increase in ${ }^{13} \mathrm{C}$ ratio above natural abundance would be 0.312 . The increase that we measured in freeze-dried cells is $(1.399 \%-1.119 \%) / 1.119 \%=0.25$, in good agreement with the expected value.

Second, the ${ }^{12} \mathrm{C}^{15} \mathrm{~N} /{ }^{12} \mathrm{C}^{14} \mathrm{~N}$ isotope ratios measured in control cells and in cells that had been supplemented with ${ }^{13} \mathrm{C}$-glycine were equivalent to the terrestrial ${ }^{15} \mathrm{~N} /$ ${ }^{14} \mathrm{~N}$ ratio. Similarly, the ${ }^{13} \mathrm{C}^{14} \mathrm{~N} /{ }^{12} \mathrm{C}^{14} \mathrm{~N}$ isotope ratios measured in cells that had been fed with ${ }^{15} \mathrm{~N}$-glycine were equivalent to the terrestrial ${ }^{13} \mathrm{C} /{ }^{12} \mathrm{C}$ ratio. These results indicate that there was no spillover of the ${ }^{13} \mathrm{C}^{14} \mathrm{~N}^{-}$signal into the ${ }^{12} \mathrm{C}^{15} \mathrm{~N}^{-}$signal and vice-versa, emphasizing the mass resolution that can be achieved by MIMS.

The differences in isotope ratios between freezedried and fixed cells that had received labeled glycine were to be expected because the cell densities-and therefore the growth stage and the metabolic activity of the cells (particularly for protein synthesis) - were different among culture dishes. In addition, the dose of isotope-labeled glycine may have been slightly different among the cultured cell populations.

Alternatively, a systematic difference might have been introduced during the sample preparation step. A lower count rate from fixed cells compared with freezedried cells may be due to a stabilization of the bio-mass of the cells, lowering the secondary ion yield as a result of chemical cross-linking. Also, the wash steps during the fixation process may selectively elute low molecular weight components of the cells, such as sugars and lipids, as well as unincorporated glycine. This may also explain the large difference in ${ }^{12} \mathrm{C}$ yield between freezedried and fixed samples, despite the lack of statistical difference between the ${ }^{12} \mathrm{C}^{14} \mathrm{~N}$ counts. For MIMS studies that will focus on small molecules or ions that may be lost during the fixation process, a freezing-based protocol has a clear advantage.

In conclusion, carbon and nitrogen isotope ratios can now be measured in subcellular volumes at natural abundance as well as at enrichment levels that are easily achievable in vitro and in situ. This necessary step allows the measure of the molecular turnover of biomolecules labeled with stable isotopes in subcellular compartments for the first time.

\section{Acknowledgments}

This work was supported by the NIH grant P41 RR 14579. The authors thank Patrick King for technical assistance.

\section{References}

1. Schoenheimer, R.; Rittenberg, D. Studies in Protein Metabolism. I. General Considerations in the Application of Isotopes to the Study of Protein Metabolism. The Normal Abundance of Nitrogen in Amino Acids. J. Biol. Chem. 1939, 127, 285-290.

2. Schoenheimer, R. The Dynamic State of Body Constituents. The Edward K. Dunham Lectures for the Promotion of the Medical Sciences 1941; Harvard University Press: Cambridge, MA, 1942, pp 1-65.

3. Hindie, E.; Hallegot, P.; Chabala, J. M.; Thorne, N. A.; Coulomb, B.; Levi-Setti, R.; Galle, P. Ion microscopy: A New Approach for Subcellular Localization of Labeled Molecules. Scan. Microsc. 1988, 2(4), 1821-1829.

4. Burns, M. S. Biological Microanalysis by Secondary Ion Mass Spectrometry: Status and Prospects. Ultramicroscopy 1988, 24(2/3), 269-281.

5. Hindie, E.; Coulomb, B.; Beaupain, R.; Galle, P. Mapping the Cellular Distribution of Labeled Molecules by SIMS Microscopy. Biol. Cell 1992, 74(1), 81-88.

6. Hindie, E.; Coulomb, B.; Galle, P. SIMS Microscopy: A Tool to Measure the Intracellular Concentration of Carbon14-Labeled Molecules. Biol. Cell 1992, 74(1), 89-92.

7. Clerc, J.; Fourre, C.; Fragu, P. SIMS Microscopy: Methodology, Problems, and Perspectives in Mapping Drugs and Nuclear Medicine Compounds. Cell. Biol. Int. 1997, 21(10), 619-633.

8. Colliver, T. L.; Brummel, C. L.; Pacholski, M. L.; Swanek, F. D.; Ewing, A. G.; Winograd, N. Atomic and Molecular Imaging at the Single-Cell Level with TOF-SIMS. Anal. Chem. 1997, 69, 2225-2231.

9. Pacholski, M. L.; Cannon, D. M., Jr.; Ewing, A. G.; Winograd, N. Static Time-of-Flight Secondary Ion Mass Spectrometry Imaging of Freeze-Fractured, Frozen-Hydrated Biological Membranes. Rapid Commun. Mass Spectrom. 1998, 12, 1232 1235.

10. Gillen, G.; Roberson, S.; Ng, C.; Stranick, M. Elemental and Molecular Imaging of Human Hair Using Secondary Ion Mass Spectrometry. Scanning 1999, 21(3), 173-181. 
11. McCandlish, C. A.; McMahon, J. M.; Todd, P. J. Secondary Ion Images of the Rodent Brain. J. Am. Soc. Mass Spectrom. 2000, 11(3), 191-199.

12. Chandra, S.; Smith, D. R.; Morrison, G. H. Subcellular Imaging by Dynamic SIMS Ion Microscopy. Anal. Chem. 2000, 72(3), 104A-114A.

13. Lorey, D. R. II.; Morrison, G. H.; Chandra, S. Dynamic Secondary Ion Mass Spectrometry Analysis of Boron from Boron Neutron Capture Therapy Drugs in Cocultures: SingleCell Imaging of Two Different Cell Types Within the Same Ion Microscopy Mield of Imaging. Anal. Chem. 2001, 73, 3947-3953.

14. Todd, P. J.; Schaaff, T. G.; Chaurand, P.; Caprioli, R. M. Organic Ion Imaging of Biological Tissue with Secondary Ion Mass Spectrometry and Matrix-Assisted Laser Desorption/ Ionization. J. Mass Spectrom. 2001, 36, 355-369.

15. Hindie, E.; Blaise, G.; Galle, P. Origin of the Cyanide Secondary Ions Emitted from Biological Tissue Under Ten $\mathrm{keV}$ Cesium (1+) Bombardment. In Proceedings of the Secondary Ion Mass Spectrometry SIMS XII International Conference; Benninghoven, A, Ed.; Wiley: Chichester, UK, 1990, pp 335-338.

16. Lousier, F.; Lefebvre, D.; Gibouin, D.; Demarty, M.; Thellier, M.; Ripoll, C. Secondary Ion Mass Spectrometry Imaging of the Fixation of ${ }^{15} \mathrm{~N}$-labeled NO in Pollen Grains. J. Microsc. 2000, 182(Pt.2), 108-115.

17. Cliff, J. B.; Gaspar, D. J.; Bottomley, P. J.; Myrold, D. D. Exploration of Inorganic $\mathrm{C}$ and $\mathrm{N}$ Assimilation by Soil Microbes with Time-of-Flight Secondary Ion Mass Spectrometry. Appl. Environ. Microbiol. 2002, 68(8), 4067-4073.
18. Slodzian, G.; Daigne, B.; Girard, F.; Boust, F.; Hillion, F. Scanning Secondary Ion analytical Microscopy with Parallel Detection. Biol. Cell 1992, 74(1), 43-50.

19. Lechene, C. Electron Probe Analysis of Small Populations of Single Cells. In Membrane Biophysics II: Physical Methods in the Study of Epithelia; Dinno, M. A.; Callahan, A. B.; Rozzell, T. C., Eds.; Alan R. Liss: New York, 1983; pp 105-132.

20. Lechene, C. Electron Probe Analysis of Cultured Cells. In Recent Advances in Electron and Light Optical Imaging in Biology and Medicine; Somlyo, A. P., Ed.; Annals of New York Academy of Sciences: New York, 1986; pp 270-283.

21. Lechene, C.; Harris, R. C. Electron Probe Analysis of Cultured Renal Cells. In Contemporary Issues in Nephrology: Modern Techniques of Ion Transport; Brenner, B. M.; Stein, J. H., Eds.; Churchill Livingstone: New York, 1987; pp 173-198.

22. Karnovsky, M. J. A Formaldehyde-Glutaraldehyde Fixative of High Osmolality. J. Cell. Biol. 1965, 27(2), A137-A138.

23. Kiernan, J. A. Histological and Histochemical Methods: Theory and Practice; 3rd ed; Butterworth-Heinemann: Oxford, 1999, p 30.

24. Abraham, E. H.; Brewslow, J. L.; Epstein, J.; Chang-Sing, P.; Lechene, C. Preparation of Individual Human Diploid Fibroblasts and Study of Ion Transport. Am. J. Physiol. (Cell Physiol.) 1985, 17, C154-C164.

25. Alberts, B.; Johnson, A.; Lewis, J.; Raff, M.; Roberts, K.; Walter, P. Molecular Biology of the Cell; 4th ed; Garland Science: London, 2002, p 66.

26. Voet, D.; Voet, J. G. Biochemistry; 2nd ed; John Wiley and Sons, Inc: New York, 1995, p 20. 